\title{
High frequency transfer of a broad host range plasmid present in an atypical strain of the fish pathogen Aeromonas salmonicida
}

\author{
Ruth-Anne Sandaa*, Øivind Enger \\ University of Bergen, Department of Microbiology, Jahnebakken 5, N-5020 Bergen, Norway
}

\begin{abstract}
We have demonstrated transfer of a naturally occurring plasmid (pRAS1), encoding multiple resistance, from atypical Aeromonas salmonicida strain 718 to a variety of marine bacteria. This plasmid exhibited a broader host range and a generally higher transfer frequency when compared to the promiscuous plasmid RP4 originating from a hospital isolate of Pseudomonas aeruginosa. The plasmid pRAS1 was transferred from $A$. salmonicida to unrelated bacterial species and even to a Gram-positive bacterium (Lactobacillus $\mathrm{sp}$.). Transfer of the plasmid was also shown to occur between A. salmonicida and 6 different bacterial isolates from fish farm sediments.
\end{abstract}

KEY WORDS: Aquaculture - Antibiotic resistance - Promiscuous plasmid

Four decades of widespread use of antibacterial agents has resulted in an increased occurrence of drugresistant bacteria. Heavily polluted milieus such as hospital sewage effluents (Fontaine \& Hoadley 1976), fish farm environments (Datta 1969, Toranzo et al. 1984), and domestic waste water (McPherson \& Gealt 1986) have proved to harbour a high number of bacteria resistant to different types of antibacterial agents.

Spread of resistance plasmids in bacteria from polluted environments may cause transfer of resistance genes to bacteria that are pathogenic to either fish or homoiothermic animals. Plasmids involved in resistance to a wide range of antibiotics have been detected in various fish pathogenic bacteria such as Aeromonas salmonicida (Aoki et al. 1972), Aeromonas hydrophila (Akashi \& Aoki 1986), Edwardsiella tarda (Aoki \& Kitao 1981), Pseudomonas fluorescens (Aoki et al. 1977), Pasteurella piscicida (Takashima et al. 1985) and Vibrio anguillarum (Aoki et al. 1974). Likewise, transferable plasmid-mediated resistance has been detected in bacterial isolates from fish farm sediments (Sandaa et al.

·E-mail: ruth.sandaa@im.uib.no
1992). In addition, transferable R-plasmids have been isolated from $A$, salmonicida isolated from cultured salmonids in Scotland and Norway (Inglis et al. 1993, H. Sørum, Norwegian College of Veterinary Medicine, Oslo, Norway, pers. comm.).

Here we report transfer of a broad host range multiple resistance plasmid indigenous to the fish pathogenic bacterium Aeromonas salmonicida strain 718 to a variety of marine bacterial species and to 6 unidentified bacterial strains isolated from fish farm sediments.

Materials and methods. Bacterial strains, bacteriophages, and growth conditions: Aeromonas salmonicida 718 (kindly provided by H. Sørum) is an atypical strain naturally harbouring the $25 \mathrm{MDa}$ conjugative plasmid, pRAS1. The plasmid was of interest to us because it carries resistance to oxytetracycline, trimethoprim, and sulfadiazine. Conjugation experiments with another plasmid, RP4, were performed using $A$. salmonicida AL2015 (kindly provided by Apothekernes Laboratorium, Tromsø, Norway) as a donor. The plasmid RP4, belonging to the IncP group (Thomas \& Helsinki 1989), is a broad host range plasmid that encodes resistance to kanamycin, ampicillin, and tetracycline (class A). Plasmid RP4 was transferred from Escherichia coli K12 to A. salmonicida AL2015 by conjugation using the membrane filter method as described by Genthner et al. (1988), with some modifications (Sandaa et al. 1992). Transconjugants were selected as blue colonies on tryptone soya agar (TSA) [30 g tryptone soya broth (Oxoid), $10 \mathrm{~g} \mathrm{NaCl}, 15 \mathrm{~g}$ agar, $1000 \mathrm{ml}$ distilled water] containing $25 \mu \mathrm{g}$ tetracycline $\mathrm{ml}^{-1}$ and $0.01 \%$ (wt/vol) Coomassie Brilliant Blue (Serva). This dye stains the outer protein layer of $A$. salmonicida, resulting in blue colonies on the agar. Plasmid transfer was verified by the plasmid screening method of Kado \& Liu (1981), modified as described by Sandaa et al. (1992), except that lysozyme was omitted in the lysis procedure. 
Escherichia coli D20-15 with the plasmid pSL18 (kindly provided by S. Levy, Dept. of Molecular Biology and Microbiology, Tufts University, Boston) that harbours the tetracycline resistance determinant class A was used for preparation of a probe against RP4, while E. coli HB101 with the plasmid pRAS1 was used for preparation of a probe against pRAS1.

A total of 12 marine bacterial strains and 6 unidentified marine bacterial isolates belonging to different biotypes (Øvreås 1991), the latter isolated from fish farm sediments, were used as recipients (Table 1). All strains were grown on the TSA medium described earlier in this section and incubated at $21^{\circ} \mathrm{C}$, except for Escherichia coli $\mathrm{HB} 101$ which was incubated at $37^{\circ} \mathrm{C}$.

Preparation of phage lysates: The bacteriophages \#1 and \#3 (kindly provided by G. Olivier, Department of Fisheries and Oceans, Halifax, Canada) were used for removing donor cells in the experiments with RP4. To produce phage lysates, $50 \mathrm{ml}$ of Brain Heart Infusion Medium (Oxoid) was inoculated with $1 \mathrm{ml}$ of a filtered $(0.2 \mu \mathrm{m})$ phage lysate and $1 \mathrm{ml}$ of an overnight culture of Aeromonas salmonicida AL2015. After 15 h of incubation with endover-end rotation at $21^{\circ} \mathrm{C}$, the lysate was centrifuged at $7400 \times g$ for $1 \mathrm{~h}$ and the supernatant was filtered through a sterile filter with pore size $0.2 \mu \mathrm{m}$. Before application in the conjugation experiments, the lysates were tested for the ability to give plaques on plates with a lawn of $A$. salmonicida AL2015.

Preparation of immunomagnetic beads: In the conjugation experiments with the plasmid pRAS1, immunomagnetic beads were used for donor cell removal (Enger \& Sandaa 1994). A total of $1 \mathrm{ml}$ of monodispersed latex beads, $2.8 \mu \mathrm{m}$ in diameter, coated with covalently linked sheep antibodies to mouse IgG antibodies (Dynal A.S., Oslo) was suspended in $5 \mathrm{ml}$ phosphate buffered saline (PBS: $150 \mathrm{mM} \mathrm{NaCl}, 10 \mathrm{mM} \mathrm{Na}_{2} \mathrm{HPO}_{4} \cdot 2 \mathrm{H}_{2} \mathrm{O}$ and $10 \mathrm{mM}$ $\mathrm{NaH}_{2} \mathrm{PO}_{4} \cdot \mathrm{H}_{2} \mathrm{O}$ mixed to give $\mathrm{pH} 7.5$ ), with $0.5 \%$ (wt/vol) bovine serum albumin (BSA, Sigma) added. A volume of $5 \mu \mathrm{l}$ of mouse IgG (monoclonal ascites antibodies) specific to Aeromonas salmonicida outer lipopolysaccharides was then added. The antibodies were kindly provided by G. Eggset, Fisheries Research, Tromsø. After incubation overnight at $4{ }^{\circ} \mathrm{C}$ on an end-over-end rotator, the beads were washed 5 times with PBS-BSA. The washes were performed by drawing the beads to the tube wall with a magnet, after which the residual liquid was aspirated before fresh buffer was added.
Mating procedure and removal of donor cells: Aliquots $(1 \mathrm{ml})$ of $\log$-phase cultures of recipient and donor, grown in tryptone soya broth (TSB), were filtered onto Unipore membrane filters with pore size $0.2 \mu \mathrm{m}$ (type 11307, Sartorius GmbH, Göttingen, Germany). Filters were incubated on TSA at $21^{\circ} \mathrm{C}$ for $24 \mathrm{~h}$. After incubation, the filters were transferred to flasks containing $1 \mathrm{ml}$ of TSB, and incubated on a rotary shaker at $21^{\circ} \mathrm{C}$ for $1 \mathrm{~h}$ to remove the bacteria from the filter. Samples were spread on TSA supplemented with $0.01 \%$ Coomassie Brilliant Blue to determine the total number of donor (blue colonies) and recipient (white colonies) cells.

In the experiments with pRAS1, donor cells were removed by incubation with the antibody-coated immunomagnetic beads. The volume of the bead suspension, containing $10^{8}$ beads $\mathrm{ml}^{-1}$, equalled the volume of the conjugation suspension. The cells were incubated with the beads in Eppendorf tubes with endover-end rotation at $4^{\circ} \mathrm{C}$ for $1 \mathrm{~h}$. During this incubation, the antibodies attached to the beads bind cells of Aeromonas salmonicida selectively. After incubation, the beads and attached donor cells were removed from the suspension by application of a magnet outside the tube. With the magnet still attached to the tube, the cell suspension (now containing mostly recipient cells) was transferred to a fresh tube. Dilutions of the cell suspension were made in sterile $70 \%$ seawater, and appropriate dilutions were plated on media selective for tetracycline resistant bacteria [TSA containing 
$25 \mu \mathrm{g}$ tetracycline $\mathrm{ml}^{-1}$ and $0.01 \%$ (wt/vol) Coomassie Brilliant Blue (Serva)]. Transconjugants were observed as white/yellow colonies on the agar plates.

Because bacteria containing the RP4 plasmid tended to bind non-specifically to immunomagnetic beads, removal of the donor (Aeromonas salmonicida cells) had to be performed by application of bacteriophages specific to $A$. salmonicida in the experiments with RP4. This was carried out by using a 1:1 mix of the 2 phage lysates produced as described above. The suspension of bacteria from the filter was diluted 1:1 with the phage lysate mix. Samples of $100 \mu l$ were then spreadplated on TSA supplemented with tetracycline $(25 \mu \mathrm{g}$ $\mathrm{ml}^{-1}$ ) and $0.01 \%$ Coomassie Brilliant Blue. Prior to plating, the plates were pre-treated with the phage lysate. Again, transconjugants were observed as white/yellow colonies on the agar plates.

Colony hybridisation: The transconjugants were purified by repeated streaking on TSA with tetracycline $\left(25 \mu \mathrm{g} \mathrm{ml}^{-1}\right)$ and Coomassie Brilliant Blue. Colonies of the transconjugants were transferred to nylon membrane filters (Hybond ${ }^{T M}-\mathrm{N}+$, Amersham, Buckinghamshire, England) with sterile Q-tips. Colony blotting was performed based on a method by Grunstein \& Hogness (1975) modified by Sambrook et al. (1989). After colony blotting, the DNA was fixed to the filter following the manufacturer's instructions (Amersham) by placing the filters in $0.4 \mathrm{M} \mathrm{NaOH}$, for $20 \mathrm{~min}$. The filters were then rinsed in $5 \times \mathrm{SSC}$ (saline sodium citrate) $(20 \times \mathrm{SSC}=$ $3 \mathrm{MNaCl}, 0.3 \mathrm{M} \mathrm{Na}$-citrate, $\mathrm{pH} 7.0$ ) for $1 \mathrm{~min}$, and dried at room temperature. The DNA probes were prepared from Escherichia coli HB101 harbouring the plasmid pRAS1 and from E. coli D2015 with the plasmid pSL18 harbouring the tetracycline resistance determinant class A. Plasmids were isolated using the Qiagen kit for plasmid preparation (Qiagen, Inc., Chatsworth, CA, USA). The pRAS1 plasmid was cut with the restriction enzyme EcoRI according to the manufacturer's instructions (Boehringer Mannheim GmbH, Mannheim, Germany). After agarose gel electrophoresis, a $4.6 \mathrm{~kb}$ DNA fragment was purified applying the Gene-Clean kit II (BIO101, Inc., La Jolla, CA, USA) for DNA purification. The pSL18 plasmid was cut by the $S m a I$ restriction enzyme, followed by purification of a $750 \mathrm{bp}$ fragment. The purified restriction DNA fragments were labelled using the nonradioactive random primed DNA labelling and DIG Luminescence Detection kit (Boehringer Mannheim GmbH) following the manufacturer's instruc- tions. The filters were hybridised with the non-radioactive pRAS1 or the tetA probe under high stringency conditions in $10 \mathrm{ml}$ of hybridisation buffer [ $50 \%$ ( $\mathrm{vol} / \mathrm{vol}$ ) formamide, $5 \times \mathrm{SSC}$, $2 \%$ blocking reagent (Boehringer Mannheim GmbH), $0.1 \% \quad N$-lauroylsarcosine and $0.02 \%$ sodium dodecyl sulphate (SDS)] for $6 \mathrm{~h}$ at $42^{\circ} \mathrm{C}$. After hybridisation, the filters were washed 2 times for $5 \mathrm{~min}$ in $2 \times \mathrm{SSC}, 0.1 \% \mathrm{SDS}$ at room temperature, and twice for $15 \mathrm{~min}$ in $0.1 \times \mathrm{SSC}, 0.1 \% \mathrm{SDS}$ at $68^{\circ} \mathrm{C}$. Hybridisation was detected using a chemiluminescent alkaline phosphatase substrate, AMPPD [3-(2'-spiroadamantane)-4-methoxy-4-( $3^{\prime \prime}$-phosphoryloxy)phenyl1,2-dioxethane, disodium salt], following the manufacturer's instructions. Hybridisation of the probe was visualised by exposure of the membrane filters to X-ray film for $20 \mathrm{~min}$. As positive and negative controls, E. coli HB101 with and without pRAS1, and A. salmonicida 2015 with RP4, were included on the filter.

Results and discussion. Plasmids that are capable of crossing the borders between bacterial families are normally defined as broad host range plasmids (Datta \& Hedges 1972, Guiney 1993). As shown in Table 2, the plasmid pRAS1 was transferred to all the recipients tested except for Shewanella putrefaciens. This means that this plasmid was transferred not only from Aeromonas salmonicida (Vibrionaceae) to other members of the same family, but also to members of other families such as the Enterobacteriaceae and Pseudomonaceae (Table 2). The plasmid even transferred to a Gram-positive bacterium Lactobacillus sp. KitaTseukamoto et al. (1993) have shown that many of the

Table 2. Transfer frequencies, calculated as number of transconjugants per donor cell, of the plasmids pRAS1 and RP4 from Aeromonas salmonicida to different marine bacterial strains and to Escherichia coli. Six isolates (V6-1 to V6-88) represent characterised but unidentified bacteria isolated from fish farm sediments. -: no transfer detected

\begin{tabular}{|lcc|}
\hline Recipients & RP4 & pRAS1 \\
\hline Escherichia coli HB101 & $6.1 \times 10^{-5}$ & $1.4 \times 10^{-2}$ \\
Lactobacillus sp. NCIMB 2019 & $4.0 \times 10^{-6}$ & $7.3 \times 10^{-4}$ \\
Photobacterium phosphoreum NCIMB 275 & - & $3.1 \times 10^{-6}$ \\
Pseudomonas putida NCMB 1960 & $1.6 \times 10^{-8}$ & $7.1 \times 10^{-6}$ \\
Pseudomonas fluorescens NCMB 1953 & $3.5 \times 10^{-5}$ & $1.8 \times 10^{-3}$ \\
Shewanella.putrefaciens NCIMB 2091 & - & - \\
V6-1 & - & $4.2 \times 10^{-5}$ \\
V6-15 & - & $1.0 \times 10^{-5}$ \\
V6-47 & - & $1.3 \times 10^{-6}$ \\
V6-48 & - & $1.6 \times 10^{-5}$ \\
V6-6 & - & $3.4 \times 10^{-5}$ \\
V6-88 & - & $1.8 \times 10^{-5}$ \\
Vibrio sp. S14 & - & $1.1 \times 10^{-5}$ \\
Vibrio anguillarum HI-10-7 & - & $3.3 \times 10^{-6}$ \\
Vibrio ordalii NCMB 2167 & - & $2.6 \times 10^{-3}$ \\
Vibrio fisheri OST 86/07 & - & $4.6 \times 10^{-4}$ \\
Vibrio fisheri NCMB 1281 & - & $1.1 \times 10^{-4}$ \\
Vibrio fisheri TEE 005 & $1.8 \times 10^{-11}$ & $4.8 \times 10^{-6}$ \\
\hline
\end{tabular}


recipients used in this study belong to distinct groups based on their $16 \mathrm{~S}$ rRNA sequences. On this basis we conclude that the pRAS1 plasmid should be regarded as a broad host range plasmid.

As a part of a broader study, the 6 sediment isolates used in this study were examined for 25 phenotypical features by Øverås (1991). Cluster analysis showed that the 6 strains belonged to different biotypes. This further emphasises the broad host range of the pRAS1 plasmid.

There is no reason to assume that the pRAS1 plasmid occurs only in the atypical Aeromonas salmonicida strain 718 from which it was first isolated. Indeed, considering its broad host range, it may as well have originated from an environmental bacterium. Occurrence of the plasmid in $A$. salmonicida may thus be a consequence of plasmid transfer to this bacterium facilitated by the use of antibiotics.

Plasmid RP4 was selected for this study for comparing the host range of the pRAS1 plasmid with that of another promiscuous plasmid. The RP4 plasmid is commonly used in plasmid transfer studies (Fry \& Day 1990, Gauthier \& Breittmeyer 1990, Schmidt et al. 1990, Schneidereit \& Schmidt 1990, van Elsas \& Trevors 1990), and information about both the host range and the transfer frequencies of this plasmid is available (Thomas \& Helsinki 1989). The RP4 plasmid, originally isolated from Pseudomonus aeruginosa (Datta et al. 1971), transfers between various Gramnegative bacteria (Thomas \& Helsinki 1989). Our results show that pRAS1 exhibits a broader host range compared to RP4. Although $27.8 \%$ of the possible recipients received RP4, as many as $94.4 \%$ received pRAS1 With one exception, transfer frequencies were higher for pRAS1 than for RP4. The transfer frequencies for RP4 seemed low compared to other studies (Datta et al. 1971, Schneidereit \& Schmidt 1990), leading us to suspect that Aeromonas salmonicida may not be an optimal donor for the RP4 plasmid.

Both plasmids showed the highest transfer frequency with Escherichia coli. pRAS1 transferred to $E$. coli at a frequency of $1.4 \times 10^{-2}$, while the corresponding frequency for $\mathrm{RP} 4$ was $6.1 \times 10^{-5}$. The plasmid pRAS1 even transferred at a frequency of $7.3 \times$ $10^{-4}$ to the Gram-positive bacterium Lactobacillus sp. Studying plasmid transfer from Gram-negative to Gram-positive bacteria, Trieu-Cuot et al. (1987) reported frequencies 3 to 4 orders of magnitude lower than our results. In their studies, however, they used constructed plasmids while the present study measured the transfer of a naturally occurring plasmid. Plasmid transfer was verified by colony hybridisation.

A possible problem in comparing the transfer frequencies of the 2 plasmids may be that the results were influenced by the use of 2 different techniques for removing donor cells. However, in a separate experiment where the 2 methods were compared, no significant differences were seen in the transfer frequencies (data not shown).

There seemed to be no correlation between the transfer frequencies for the pRAS1 plasmid and the taxonomic position of the recipient strains. This is clearly shown by the high variation in the transfer frequencies among the 5 vibrio strains tested.

Using Escherichia coli as a recipient, Toranzo et al. (1984) studied transfer of plasmids in bacteria isolated from cultured rainbow trout. In their experiment, the transfer frequencies ranged from $10^{-4}$ to $10^{-7}$. In other experiments where $E$. coli has been used as a recipient for a plasmid isolated from the natural environment similar results have been obtained (Mach \& Grimes 1982, Gauthier et al. 1985). In our experiment, the plasmid was transferred to $E$. coli at a frequency of approximately $10^{-2}$, indicating that this plasmid has a high frequency of transfer.

With donor cell removal performed by application of immunomagnetic beads the limit for detection of transconjugants was 3 cells $\mathrm{ml}^{-1}$, while the corresponding number for the phage counter-selection method was 6 cells $\mathrm{ml}^{-1}$. Thus, failure to detect transfer of pRAS1 or RP4 did not prove lack of transfer, as transfer may occur at very low frequencies.

In a recent study Sandad \& Enger (1994) showed that pRAS1 plasmid spreads at high frequencies in marine sediments even in the absence of antibiotics that would select for antibiotic resistance. When tetracycline was present, this plasmid, encoding tetracycline resistance, showed an even higher transfer frequency. In both cases, it was shown that the plasmid spread to a wide variety of biotypes and that the plasmid was still present when the experiment was terminated at $44 \mathrm{~d}$ following its initiation.

It has been shown that low concentrations of oxytetracycline may be present in the sediments beneath the fish cages for more than a year after medication (Samuelsen 1988). Such low concentrations do not necessarily kill the bacteria, but promote development of transferable resistance finally leading to emergence of promiscuous plasmids like the pRAS1 plasmid. Simultaneous occurrence of transferable genetic elements and selective pressure, e.g. antibacterial agents, could possibly promote maintenance and spread of antibiotic resistance in the environment. This may create a pool of resistance genes that could transfer to bacteria of veterinary and medical importance.

Acknowledgements. We thank H. Sørum for donating the plasmid-containing strain Aeromonas salmonicida 718 and for help with the design of the DNA probe. G. Olivier and G Eggset are thanked for the donation of bacteriophages and 
monoclonal antibodies, respectively. This work was supported by grants from The Council of Nordic Ministers (R.-A. S.) and The Research Council of Norway (NFR) (Ø.E.).

\section{LITERATURE CITED}

Akashı A, Aoki T (1986) Characterization of transferable R plasmids from Aeromonas hydrophila. Bull Jap Soc scient Fish 52:649-655

Aoki T, Egusa S, Arai T (1974) Detection of R factors in naturally occurring Vibrio anguillarum strains. Antimicrob Agents Chemother 6:534-538

Aoki T, Egusa S, Yada C, Watanabe T (1972) Studies of drug resistance and $R$ factors in bacteria from pond cultured salmonids. Jap J Microbiol 16:233-238

Aokı T, Kitao T (1981) Drug resistance and transferable R plasmids in Edwardsiella tarda from fish culture ponds. Fish Pathol 15:277-281

Aoki T, Kitao T, Arai T (1977) R plasmids in fish pathogens. In: Mitsuhashi S, Rosival L, Krcméry V (eds) Plasmids medical and theoretical aspects. Prague: AvicenumCzechoslovak Medical Press, Berlin, p 39-45

Datta N (1969) Drug resistance and $R$ factors in the bowel bacteria of London patients before and after admission to hospitals. Br med J 2:407-411

Datta N, Hedges RW (1972) Host range of R factor. J gen Microbiol 70:453-460

Datta N, Hedges RW, Shaw EJ, Sykes RB, Richmond $\mathrm{MH}$ (1971) Properties of an $R$ factor from Pseudomonas aeruginosa. J Bacteriol 108:1244-1249

Enger $\varnothing$, Sandaa RA (1994) Immunomagnetic beads as a tool in conjugation experiments. J microbiol Meth 19:111-115

Fontaine FD III, Hoadley AW (1976) Transferable drug resistance associated with coliforms isolated from hospital and domestic sewage. Health Lab Sci 13:238-245

Fry JC, Day MJ (1990) Plasmid transfer and the release of genetically engineered bacteria in nature: a discussion and summary. In: Fry JC, Day MJ (eds) Bacterial genetics in natural environments. Chapman and Hall, London, $p$ $243-250$

Gauthier MJ, Breittmayer VA (1990) Gene transfer in marine environments. In; Fry JC, Day MJ (eds) Bacterial genetics in natural environments. Chapman and Hall, London, $p$ $100-110$

Gauthier MJ, Cauvin F, Breittmayer JB (1985) Influence of salts and temperature on the transfer of mercury resistance from a marine pseudomonad to Escherichia coli. Appl environ Microbiol 50:38-50

Genthner FJ, Chatterjee P, Barkay T, Bourquin AW (1988) Capacity of aquatic bacteria to act as recipients of plasmid DNA. Appl environ Microbiol 54:115-117

Grunstein M, Hogness DS (1975) Colony hybridization: a method for the isolation of cloned DNAs that contain a specific gene. Proc natl Acad Sci USA 72:3961-3965

Guiney DG (1993) Broad host range conjugative and mobilizable plasmids in Gram-negative bacteria. In: Clewell DB (ed) Bacterial conjugation. Plenum Press, New York, p $75-97$

Inglis V, Yimer E, Bacon EJ, Ferguson S (1993) Plasmid-medj- ated antibiotic resistance in Aeromonas salmonicda isolated from Atlantic salmon, Salmo salar, L., in Scotland. J Fish Dis 16:593-599

Kado Cl, Liu ST (1981) Rapid procedure for detection and isolation of large and small plasmids. J Bacteriol 145: $1365-1373$

Kita-Tseukamoto K, Oyaizu H, Nanba K, Simidu U (1993) Phylogenetic relationship of marine bacteria mainly members of the family Vibrionaceae, determinded on the basis of 16S rRNA sequences. Int J Syst Bacteriol 43:8-19

Mach PA, Grimes DJ (1982) R-plasmid transfer in a wastewater treatment plant. Appl environ Microbiol 44: 1395-1403

McPherson P, Gealt MA (1986) Isolation of indigenous wastewater bacterial strains capable of mobilizing plasmid pBR325. Appl environ Microbiol 51:904-909

Øvreás L (1991) Karakterisering av plasmider fra sediment under et marint oppdrettsanlegg. Cand Scient thesis, University of Bergen

Sambrook J, Fritsch EF, Maniatis T (1989) Molecular cloning: a laboratory manual, 2nd edn. Cold Spring Harbor Laboratory Press, Cold Spring Harbor, NY

Samuelsen OB (1988) Degradation of oxytetracycline in seawater at two different temperatures and light intensities, and the presence of oxytetracycline in the sediment from a fish farm. Aquaculture 83:7-16

Sandaa RA, Enger $\varnothing$ (1994) Transfer in marine sediments of the naturally occurring plasmid pRAS1 encoding multiple antibiotic resistance. Appl Environ Microbiol 60: $4234-4238$

Sandaa RA, Torsvik VL, Goksøyr J (1992) Transferable drug resistance in bacteria from fish farm sediments. Can $J$ Microbiol 38:1061-1065

Schmidt FRJ, Rosien J, Brokamp A (1990) The role of soil bacteria in risk assessment analysis. In: Fry JC, Day MJ (eds) Bacterial genetics in natural environments. Chapman and Hall, London, p 207-215

Schneidereit H, Schmidt FRJ (1990) The use of a Sesbania rostrata microcosm for studying gene transfer among microorganisms. In: Fry JC, Day MJ (eds) Bacterial genetICS in natural environments. Chapman and Hall, London, p $182-187$

Takashima N, Aoki T, Kitao T (1985) Epidemiological surveillance of drug-resistant strains of Pasteurella piscicida. Fish Pathol 20:209-217

Thomas CM, Helsinki DR (1989) Vegetative replication and stable inheritance of IncP plasmids. In: Thomas CM (ed) Promiscuous plasmids of Gram-negative bacteria. Academic Press, London, p 1-25

Toranzo AE, Combarra P, Lemos ML, Barja JL (1984) Plasmid coding for transferable drug resistance in bacteria isolated from cultured rainbow trout. Appl environ Microbiol 48: $872-877$

Trieu-Cuot P, Carlier C, Martin P, Courvalin P (1987) Plasmid transfer by conjugation from Escherichia coli to Gram-positive bacteria. FEMS Microbiol Lett 48:289-294

van Elsas JD, Trevors JT (1990) Plasmid transfer to indigenous bacteria in soil and rhizosphere: problems and perspectives. In: Fry JC, Day MJ (eds) Bacterial genetics in natural environments. Chapman and Hall, London, p 188-199

Manuscript first received: October 20, 1994

Revised version accepted: July 21, 1995
Responsible Subject Editor: T. Evelyn, Nanaimo, British Columbia, Canada 